\title{
Fanconi's anemia in dentistry: a case report and brief literature review
}

\author{
Anemia de Fanconi em odontologia: relato de caso e \\ breve revisão da literatura
}

\begin{abstract}
Purpose: To present a critical analysis of the dental literature about the oral, skeletal and developmental manifestations associated with Fanconi's anemia (FA) and to describe a clinical case.

Case description: Patient: male, Caucasian, 18 years-old. At the physical exam, the patient's appearance was roughly that of a 12-year-old child. The oral exam revealed carious lesions, gingivitis, bilateral crossbite and anterior open bite. Several teeth were absent and several primary teeth were present.

Conclusion: The review of the literature reveals a heterogeneous pattern for the oral manifestations of FA, as observed in the case described in the present report. The most common oral manifestations of the disease are gingivitis, periodontitis, dental agenesis and squamous cell carcinoma.
\end{abstract}

Key words: Fanconi's anemia; dentistry; diagnosis

\section{Resumo}

Proposta: $\bigcirc$ objetivo deste estudo foi realizar uma análise crítica da literatura considerando as manifestações bucais, esqueléticas e de desenvolvimento associadas à anemia de Fanconi (AF) e apresentar um caso clínico.

Descrição do caso: Trata-se de um paciente branco, sexo masculino, de 18 anos de idade, com aparência de uma criança de aproximadamente 12 anos de idade. Ao exame bucal observaram-se lesões de cárie, gengivite, mordida cruzada bilateral e mordida aberta anterior. Vários dentes permanentes estavam ausentes e muitos dentes decíduos ainda estavam presentes.

Conclusão: A revisão crítica da literatura revelou um padrão heterogêneo com relação às manifestações bucais da AF, como observado no caso clínico descrito. As manifestações bucais mais comuns da doença são gengivite, periodontite, agenesia dental e carcinoma de células escamosas.

Palavras-chave: Anemia de Fanconi; odontologia; diagnóstico

\author{
Saulo Gabriel Moreira Falci a \\ Patricia Corrêa-Faria a \\ Juliana Tataounoff $b$ \\ Cássio Roberto Rocha dos Santos " \\ Leandro Silva Marques d
}

a Graduate Program, Federal University of Vales do Jequitinhonha e Mucuri, Diamantina, MG, Brazil

b Private clinic, Hospital Irmandade Nossa Senhora da Saúde, Diamantina, MG, Brazil

cDiscipline of Oral and Maxillofacial Surgery, Department of Dentistry, Federal University of Vales do Jequitinhonha e Mucuri, Diamantina, MG, Brazil

dDiscipline of Pediatric Dentistry, Department of Dentistry, Federal University of Vales do Jequitinhonha e Mucuri, Diamantina, MG, Brazil
Correspondence:

Saulo Gabriel Moreira Falci

Universidade Federal dos Vales do

Jequitinhonha e Mucuri

Rua da Glória, 187 - Prédio

Clínica de Cirurgia Bucal, Campus I

Diamantina, MG - Brasil

39100-000

E-mail:saulofalci@hotmail.com

Received: March 25, 2011

Accepted: September 23, 2011

Conflict of Interest Statement: The authors state that there are no financial and personal conflicts of interest that could have inappropriately influenced their work.

Copyright: (C) 2011 Falci et al.; licensee EDIPUCRS. This is an Open Access article distributed under the terms of the Creative Commons AttributionNoncommercial-No Derivative Works 3.0 Unported License. 


\section{Introduction}

Fanconi's anemia (FA) is a rare recessive autosomal disease with an approximate prevalence of 1:350,000 births $(1,2)$, affecting males twofold more than females (3). FA can cause blood disorders, such as progressive bone marrow failure, bone marrow fibrosis, leukopenia and thrombocytopenia (4), as well as multiple congenital abnormalities, development disorders and an increased predisposition to malignant tumors (5). Approximately one third of affected individuals exhibit no congenital signs of the disease; diagnosis in such cases is generally determined after the first decade of life, when development abnormalities become apparent (2,6-9).

The oral manifestations of FA are melanin pigmentation of the oral mucosa, hematomas on the upper and lower lips, aphthous ulcers, traumatic injuries, angular cheilitis, herpes simplex lesions, gingival bleeding, periodontal disease, supernumerary teeth, dental agenesis, taurodontia, root dilacerations and squamous cell carcinoma (2,10-12).

The diagnosis of FA in the dental clinical practice is important because this disease can compromise the growth and development of the entire stomatognathic system. However, the literature shows that each case has its own peculiarities, which hinders any standardized conduct for the diagnosis of the oral manifestations associated with FA.

The aim of the present paper was to carry out a critical analysis of the literature considering oral, skeletal and development manifestations associated with FA and describe a clinical case.

\section{Case description}

The patient was male, Caucasian, 18 years-old. His medical and family history showed that his parents were not blood-related; their first child was diagnosed with Fanconi's anemia at 7 years-old died at 11 years-old due to a lack of a compatible bone marrow donor. The patient underwent a bone marrow transplant at 4 years-old; his sister was not affected by the disease and was the bone marrow donor. The patient underwent periodic blood exams every two months, which were reported to be within the normality range.
The physical exam showed that the patient was short and underweight for his age, with congenital malformations of his arms and skin pigmentation. The patient's appearance was roughly that of a 12-year-old child (Fig. 1A and B).
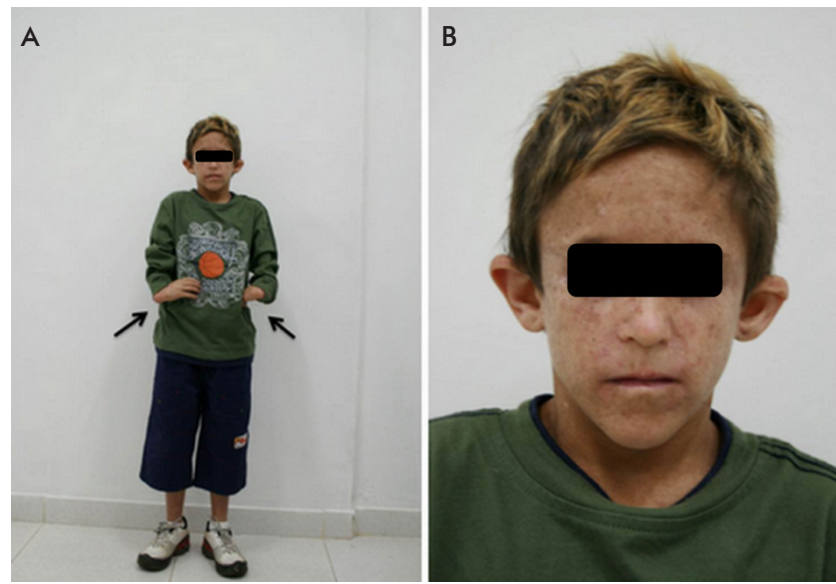

Fig. 1. (A) Photographs of the entire body of the patient, showing malformation of his right hand, absence of his left hand (arrows), short stature and low weight for his age. (B) Close-up of the patient's face, showing the characteristic skin pigmentation of FA patients.

The only dental procedure carried out was the extraction of a primary tooth under local anesthesia. The oral exam revealed no soft tissue lesions, but there is presence of carious lesions in several teeth, gingivitis, bilateral crossbite and anterior open bite. Several teeth were absent and many primary teeth were present, along with the deformed anatomy of tooth 16 (Fig. 2A, B and C). Panoramic radiography (Fig. 3A) showed impacted teeth, microdontia and agenesis of several teeth. Lateral teleradiography (Fig. 3B) showed the impacted maxillary right central incisor, with accentuated root curvature and counter-clockwise rotation of the crown, open gonial angle and absence of a defined occlusal plane. Dental treatment addressed the patient's aesthetic and functional needs, which significantly contributed to improving his quality of life.
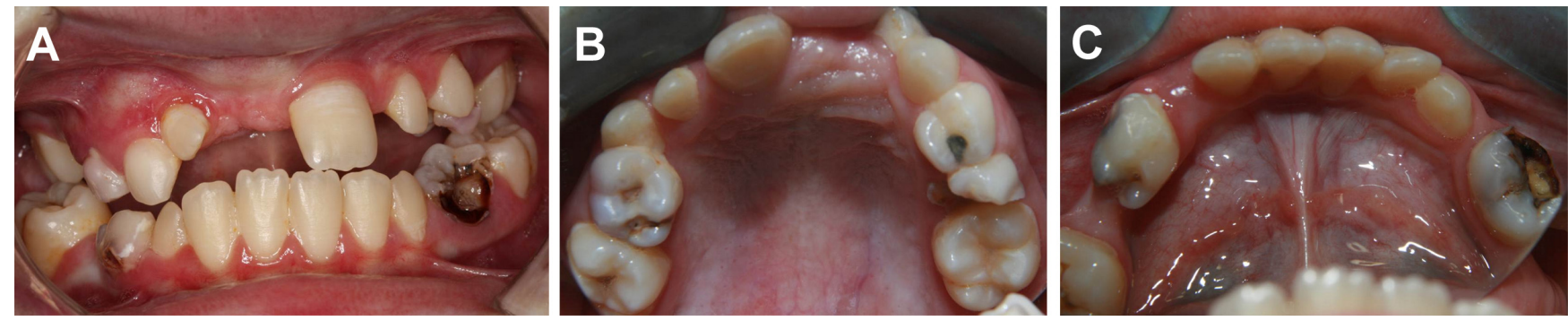

Fig. 2. (A) Frontal view of occlusion shows poor oral health, with many carious lesions and gingivitis, particularly in the region of the maxillary right lateral incisor, and large amount of dental plaque. (B) Occlusion view of the maxilla shows several caries and absence of many teeth. (C) Occlusion view of the mandible shows several caries and absence of many teeth. 


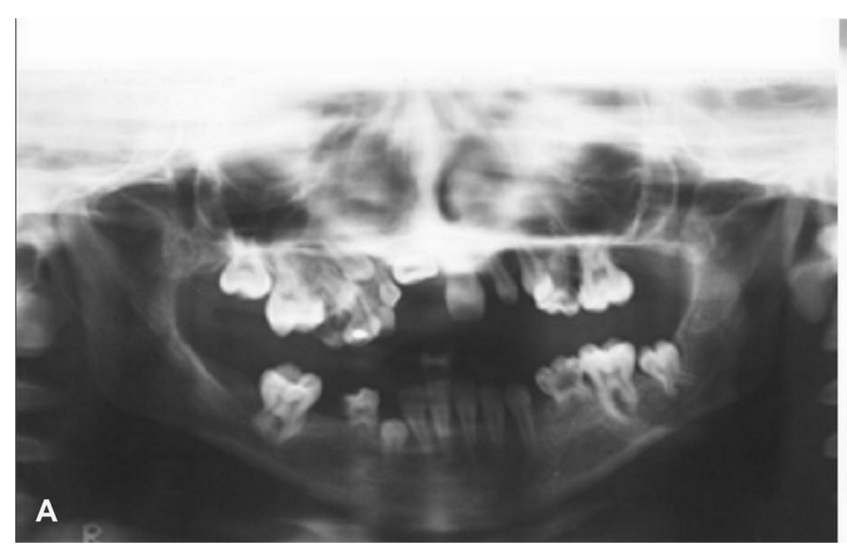

\section{Literature review and Discussion}

A review of the literature was conducted on the information collected from the Medline database (www. ncbi.nim.nih.gov) between January 1965 and April 2010, with cross-referencing using the terms "anemia and Fanconi and dentistry". Twenty-eight scientific papers were selected: 20 were case reports, five addressed the pathogenesis and systemic manifestations of the disease and three were studies specifically related to the oral manifestations of FA. Data were collected on sample size, age, gender, ethnic group, year of publication, oral manifestations, skeletal manifestations and development disorders (Table 1).

The main FA-associated oral manifestations reported in the literature were gingivitis $(41.5 \%)$, periodontitis $(22.3 \%)$, rotated teeth $(22.3 \%)$ and agenesis $(20.2 \%)$. These abnormalities also occurred in the patient described in the present case, with the exception of periodontitis. On the other hand, the patient described here had a compromised oral health, with several caries and dental plaque, which could predispose to medium-term periodontitis if no intervention were carried out.

The high predisposition to periodontal disease and gingivitis in patients with FA may be related to the frequent immune system deficiency, anemia and leucopenia in affected individuals. Moreover, FA treatment with immunosuppressant agents, such as corticosteroids, may further reduce the immunological defense leading to higher risk for periodontal disease (24). A low number of platelets may also be associated with gingival bleeding (3). However, in 33 patients with FA, Araújo et al. (12) found that deficient oral hygiene was the most common factor associated with periodontal disease and gingivitis, and no significant association of number of platelets was found with periodontal disease or gingivitis.

Beside dental alterations, FA causes congenital disorders, such as bifid thumbs, malformations of hands and arms, splotches on the skin, gastrointestinal disorders and genital anomalies $(2,12,23)$. Developmental disorders may also occur, such as microcephaly and growth deficiency. The short stature of these patients is related to deficiency of

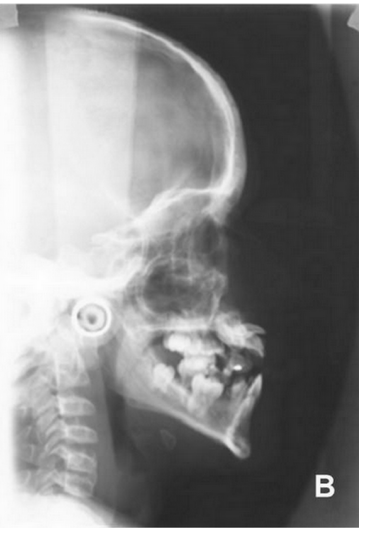

Fig. 3. (A) Panoramic x-ray shows impacted teeth and dental agenesis. (B) Lateral teleradiograph of the face shows an impacted and rotated maxilary right central incisor, open gonial angle and absence of a defined occlusal plane. growth hormone, which affects approximately $81 \%$ of FA individuals (28). Koubik et al. (28) found that bone and tooth age in patients with FA was lower than their chronological age. The patient described in the present case report also was short and had skin pigmentation and malformation of arms and hands, with bone and tooth age lower than his chronological age.

The literature only presents data on prevalence of dental development disorders $(7,11,12)$, and the genetic aspects associated with dental malformation in patients with FA, such as agenesis and taurodontia, remain unclear. In the case described here the patient had agenesis, microdontia, impacted teeth and dental rotation. Other dental-skeletal alterations were also present, such as crowding, bilateral crossbite, anterior open bite and open gonial angle. The reduction in growth factors possibly account for these problems.

In patients with FA there is a high risk $(11.7 \%)$ for development of oral squamous cell carcinoma $(2,5,26)$. Öksüzoglu and Yalçın (25) found that 14 out of 40 FA cases with squamous cell carcinoma had lesions on the tongue. In the case reported here, there was no lesion indicative of squamous cell carcinoma or any other apparent lesions.

Patients with FA have a short life expectancy, generally three decades, due to occurrence of severe health problems, such as multiple bone marrow failure, leukemia and tumors (28). Transplantation is the definitive treatment when progressive bone marrow failure occurs, but the necessary procedures, such as chemotherapy, use of immunosuppressant agents and radiotherapy, predispose to further development of carcinomas, particularly in the head and neck region $(9,26)$.

Patients with FA require close follow-up of an interdisciplinary team, including an endocrinologist for the assessment and treatment of developmental disorders, a hematologist for the control of anemia and an oncologist for the diagnosis and treatment of tumors. This critical review of the literature reveals a heterogeneous pattern regarding the oral manifestations of FA, which requires that the dentist has appropriate training and participates in the interdisciplinary team responsible for the diagnosis and treatment of these individuals. 
Table 1. Main characteristics of patients affected by Fanconi's anemia.

\begin{tabular}{|c|c|c|c|c|c|c|c|}
\hline Reference & Cases & Age & Gender & Ethnicity & Oral manifestations & Skeletal manifestations & Development disorders \\
\hline Otan et al. (1) & 1 & 16 & $\mathrm{~F}$ & & $\begin{array}{l}\text { GT / Blister / hyper- } \\
\text { pigmentation in skin }\end{array}$ & & $\begin{array}{l}\text { Short stature / hypoplasia } \\
\text { of right thumb }\end{array}$ \\
\hline Gasparini et al. (2) & 1 & 27 & $M$ & White & SCC & & \\
\hline Schofield and Worth (3) & 1 & 27 & $\mathrm{~F}$ & & $\mathrm{CR} / \mathrm{GT} / \mathrm{PD} / \mathrm{SCC}$ & & \\
\hline Shofield and Abbot (3) & 1 & 24 & $\mathrm{~F}$ & & $\begin{array}{l}\text { CR / PD / GT / Pigmentation } \\
\text { in neck region }\end{array}$ & & Low intelligence \\
\hline Tekcicek et al. (7) & 26 & $2-18$ & M17/F9 & & $\begin{array}{l}\text { GT } 35 \% \text { / DA } 4 \% \text { / AG } 26 \% \text { / } \\
\text { MD } 44 \% \text { / lingual saburra } 12 \% \text { / } \\
\text { papillary hypertrophy } 4 \%\end{array}$ & & \\
\hline Gomes et al. (10) & 1 & 23 & $\mathrm{~F}$ & White & $\begin{array}{l}\text { GT/MD (18 and } 28 \text { / necrosis } \\
\text { of nasal-orbital tissue, } \\
\text { splotches on skin }\end{array}$ & & Short stature \\
\hline Açikgoz et al. (1 1) & 15 & $6-24$ & M 11/F 4 & & $\begin{array}{l}\text { GT } 66.66 \% \text { / PD } 20 \% \text { / } \\
\text { ET } 6.66 \% \text { / AG } 6.66 \% \text { / } \\
\text { commissural fissure 13.33\% / } \\
\text { blister } 13.33 \% \text { / HP } 33.33 \%\end{array}$ & & \\
\hline Araujo et al. (12) & 33 & $2-28$ & M15/F18 & & $\begin{array}{l}\text { GT+PD } 36.36 \% \text { / AG } \\
27.28 \% \text { / TD } 3.03 \% \text { / dental } \\
\text { malformation } 9.09 \% \text { / } \\
\text { tooth rotation } 63.64 \% \text { / } \\
\text { pigmentation on tongue, gums } \\
\text { or floor of the mouth } 45.45 \% \text { / } \\
\text { aphthous ulcer } 9.09 \% \text {. }\end{array}$ & & $\begin{array}{l}\text { Hand or radius anomaly } \\
45.45 \% \text { / thumb anomaly } \\
12.12 \% \text { / foot anomaly } \\
3.03 \%\end{array}$ \\
\hline Sarna et al. (13) & 1 & 7 & M & & Hyper-pigmentation/SCC/GT & & \\
\hline Joho and Marechaux (14) & 1 & 19 & $\mathrm{~F}$ & & $\mathrm{AT} / \mathrm{EH} / \mathrm{Al} / \mathrm{MG} / \mathrm{DA}$ & Claviform hands & $\begin{array}{l}\text { Short stature / average } \\
\text { intelligence }\end{array}$ \\
\hline Kennedy and Hart (15) & 1 & 20 & $\mathrm{~F}$ & & Pigmentation in skin / SCC & Extra thumbs & $\begin{array}{l}\text { Short stature /delayed } \\
\text { bone age }\end{array}$ \\
\hline Kanplan et al. (16) & 1 & 13 & $\mathrm{~F}$ & Black & CCE & $\begin{array}{l}\text { Absence of thumbs / } \\
\text { scoliosis }\end{array}$ & \\
\hline Opinya et al. (17) & 1 & 24 & $M$ & & $\begin{array}{l}\text { GT / juvenile PD / MD / } \\
\text { Pigmentation in mucosa and } \\
\text { palate / hairy, blue tongue }\end{array}$ & & Short stature \\
\hline Lau et al. (18) & 1 & 12 & $M$ & & $\mathrm{EH} / \mathrm{CR} / \mathrm{AG}$ & & Rickets \\
\hline Morizaki et al. (19) & 1 & 12 & $M$ & Mulatto & Dental attrition & $\begin{array}{l}\text { Growth deficiency of } \\
\text { skull and middle third } \\
\text { of face }\end{array}$ & $\begin{array}{l}\text { Short stature / delayed } \\
\text { bone age / delayed tooth } \\
\text { age }\end{array}$ \\
\hline Bradford et al. (20) & 1 & 20 & $\mathrm{~F}$ & & SCC & & \\
\hline Lustig et al. (21) & 1 & 32 & $\mathrm{~F}$ & White & $\begin{array}{l}\text { Brownish pigmentation / } \\
\text { caries / AG / PD / CCE }\end{array}$ & & Short stature \\
\hline Somers et al. (22) & 1 & 17 & $M$ & & SCC & & \\
\hline Jansisyanont et al. (23) & 1 & 24 & $\mathrm{~F}$ & White & $\begin{array}{l}\text { Tan splotches on skin / } \\
\text { leukoplakia and erythroplasia } \\
\text { on tongue / SCC }\end{array}$ & $\begin{array}{l}\text { Abnormality in arms } \\
\text { and hands / absence of } \\
\text { thumbs on both hands }\end{array}$ & Short stature \\
\hline Nowzari et al. (24) & 1 & 11 & $M$ & White & GT / DP / AG & $\begin{array}{l}\text { Bifid thumbs / } \\
\text { Incomplete radius } \\
\text { development / spinal } \\
\text { malformation / } \\
\text { abnormal ribs }\end{array}$ & $\begin{array}{l}\text { Growth disorder / } \\
\text { learning difficulty / } \\
\text { microcephaly / } \\
\text { microphthalmia / } \\
\text { appearance of 3-year-old }\end{array}$ \\
\hline Oksüzoğlu and Yalçın (25) & 1 & 29 & $\mathrm{~F}$ & & $\begin{array}{l}\text { SCC / generalized } \\
\text { pigmentation on skin }\end{array}$ & & $\begin{array}{l}\text { Short stature / } \\
\text { microcephaly / deformed } \\
\text { right thumb / petechiae }\end{array}$ \\
\hline Salum et al. (26) & 1 & 12 & $M$ & White & SCC & & \\
\hline Saleh and Stephen (27) & 1 & 16 & $M$ & & $\begin{array}{l}\text { GT / PD / CR / Pigmentation } \\
\text { of mucosa, tongue and palate }\end{array}$ & & Short stature \\
\hline
\end{tabular}

$\mathrm{GT}=$ Gingivitis; $\mathrm{PD}=$ Periodontal disease $; \mathrm{CR}=$ Caries; $\mathrm{SCC}=$ squamous cell carcinoma; $\mathrm{DA}=$ dental attrition; $\mathrm{AT}=$ absent teeth; $\mathrm{MD}=\mathrm{Microdontia} ; \mathrm{Al}=\mathrm{Amelogenesis}$ imperfect; $\mathrm{EH}=$ enamel hypoplasia; $\mathrm{AG}=$ Agenesia; $\mathrm{ET}=$ Extra tooth; $\mathrm{TD}=$ Taurodontia; $\mathrm{HP}=$ Herpes; $M G=$ Macroglossia; $M=M a l e ; F=$ Female.

\section{Acknowledgments}

We would like to thank CAPES (Coordination for the Improvement Staff of Superior Level) for the financial support to perform this study. 
1. Otan F, Açikgöz G, Sakallioglu U, Özkan B. Recurrent aphthous ulcers in Fanconi's anaemia: a case report. Int J Paediatr Dent 2004;14:214-7.

2. Gasparini G, Longobardi G, Boniello R, Di Petrillo A, Pelo S. Fanconi anemia manifesting as a squamous cell carcinoma of the hard palate: a case report. Head Face Med 2006;13;2:1

3. Schofield IDF, Worth AT. Malignant mucosal change in Fanconi's anemia. J Oral Surg 1980;38:619-22.

4. Schofield IDF, Abbot WG. Review of aplastic anaemia and report of a rare case (Fanconi type). Dent J 1978;44:106-8.

5. Hermsen MAJA, Xie Y, Rooimans MA, Meijer GA, Baak JP, Plukker JT, et al. Cytogenetic characteristics of oral squamous cell carcinomas in Fanconi anemia. Fam Cancer $2001 ; 1: 39-43$.

6. Dokal I. Fanconi's anaemia and related bone marrow failure syndromes. Br Med Bull 2006;77-8:37-53.

7. Tekcicek M, Tavil B, Cakar A, Pinar A, Unal S, Gumruk F. Oral and dental findings in children with Fanconi anemia. Pediatr Dent 2007;29:248-52.

8. Dokal I. Fanconi anemia is a highly penetrant cancer susceptibility syndrome. Haematologica 2008;93:486-8.

9. Dokal I, Vulliamy T. Inherited aplastic anaemias/bone marrow failure syndromes. Blood Rev 2008;22:141-53.

10. Gomes MF, Teixeira RTS, Plens G, Silva MM, Pontes EM, da Rocha JC. Naso-orbicular tissue necrosis by Streptococcus parasanguis in a patient with Fanconi anemia: Clinical and laboratory aspects. Quintessence Int 2004;35:572-6.

11. Açikgöz A, Ozden FO, Fisgin T, Açikgöz G, Duru F, Yarali N, et al. Oral and dental findings in Fanconi's anemia. Pediatr Hematol Oncol 2005;22:531-9.

12. Araujo MR, Oliveira Ribas M, Koubik AC, Mattioli T, de Lima AA, França BH. Fanconi's anemia: clinical and radiographic oral manifestations. Oral Dis 2007;13:291-5.

13. Sarna G, Tomasaulu P, Lotz MJ, Bubinak JF, Shulman NR. Multiple neoplasms in two siblings with a variant form of Fanconi's anemia. Cancer 1975;36:1029-33.

14. Joho JP, Marechaux SC. Microdontia: a specific tooth anomaly: report of case. ASDC J Dent Child 1979;46:483-6.

15. Kennedy AW, Hart WR. Multiple squamous cell carcinomas in Fanconi's

16. Kanplan MJ, Sabio H, Wanebo HJ, Cantrell RW. Squamous cell carcinoma in the immunosuppressed patient: Fanconi's anemia. Laryngoscope 1985;95:771-5.

17. Opinya GN, Kaimenyi JT, Meme JS. Oral findings in Fanconi's anemia. A case report. J Periodontol 1988;59:461-3.

18. Lau KK, Bedi R, O'Donnell D. A case of Fanconi syndrome with associated hypodontia. Br Dent J 1988;165:292-4.

19. Morizaki I, Abe K, Sobue S. Orofacial manifestations in a child with Fanconi's syndrome. Oral Surg Oral Med Oral Phatol 1989;68:171-4.

20. Bradford CR, Hoffman HT, Wolf GT, Carey TE, Baker SR, McClatchey KD. Squamous carcinoma of the head and neck in organ transplant recipients: possible role of oncogenic viruses. Laryngoscope 1990;100:190-4.

21. Lustig JP, Lugassy G, Neder A, Sigler E. Head and neck carcinoma in Fanconi's anemia: report of a case and review of the literature. Eur J Cancer B Oral Oncol 1995;31B: 68-72.

22. Somers GR, Tabrizi SN, Tiedemann K, Chow CW, Garland SM, Venter DJ. Squamous cell carcinoma of tongue in a child with Fanconi anemia: a case report and review of the literature. Pediatr Pathol Lab Med 1995;15:597-607.

23. Jansisyanont P, Pazoki A, Ord RA. Squamous cell carcinoma of the tongue after bone marrow transplantation in a patient with Fanconi's anemia. J Oral Maxillofac Surg 2000;58:1454-7.

24. Nowzari H, Jorgensen MG, Ta TT, Contreras A, Slots J. Aggressive periodontitis associated with Fanconi's anemia. A case report. J Periodontol 2001;72:1601-6.

25. Oksüzoğlu B, Yalçın S. Squamous cell carcinoma of the tongue in a patient with Fanconi's anemia: a case report and review of the literature. Ann Hematol 2002;81:294-8.

26. Salum FG, Martins GB, de Figueiredo MA, Cherubini K, Yurgel LS, Torres-Pereira C. Squamous Cell Carcinoma of the Tongue After Bone Marrow Transplantation in a Patien with Fanconi Anemia. Braz Dent J 2006;17:161-5.

27. Saleh A, Stephen LX. Oral manifestations of Fanconi's anaemia: a case report. SADJ 2008;63:28-31.

28. Koubik AC, França BH, Ribas Mde O, de Araújo MR, Mattioli TM, de Lima AA. Comparative Study of Chronological, Bone, and Dental Age in Fanconi's Anemia. J Pediatr Hemato Oncol 2006;28:260-2. 